\title{
Shear Bond Strengths of a Single-Step Bonding System to Enamel and Dentin
}

Toru NIKAIDO, Masatoshi NAKAJIMA, Takashi HIGASHI, Nobuharu KANEMURA, Patricia N. R. PEREIRA and Junji TAGAMI

Department of Operative Dentistry, Faculty of Dentistry

Tokyo Medical and Dental University

1-5-45, Yushima, Bunkyo-ku, Tokyo 113, Japan

Received January 16, 1997/Accepted March 11, 1997

\begin{abstract}
An experimental primer was developed as a single-step bonding system for resin-modified glass ionomer cements (GIC). Efficacy of this primer on adhesion of resin-modified GICs and resin composite to enamel and dentin was evaluated by shear bond test and SEM observation. Good bond strengths to enamel were obtained $(>11 \mathrm{MPa}$ ), whereas significantly low bond strengths to dentin were obtained using a single coat of the primer. However, double-coating improved the bond strengths to dentin $(>8 \mathrm{MPa})$. SEM observations indicated that the primer functioned as a mild conditioner to remove the smear layer on enamel or dentin surfaces. A hybrid layer was observed at the cross-sectional view of the GIC/dentin interface. These findings suggested that good adhesion to enamel and dentin could be achieved using a single-step bonding system.
\end{abstract}

Key words : Primer, Glass ionomer cement, Shear bond strength

\section{INTRODUCTION}

Glass ionomer cements (GIC) have been successfully used for esthetic restorations of cervical lesions $\mathrm{s}^{1,2)}$. They are expected to be cariostatic through fluoride release $\mathrm{s}^{3,4}$. Resin-modified GICs were introduced in the late $1980 \mathrm{~s}^{5,6)}$, and incorporated a lightcuring system in addition to the conventional acid-base reaction ${ }^{7)}$. Recently, hybrid material, such as "compomer", has also been developed with physical and mechanical properties similar to those of resin composites ${ }^{8)}$.

The bond strengths of resin-modified GICs to enamel and dentin were improved with a conditioner or a primer ${ }^{9,10)}$. A simple bonding step for adhesion to tooth substrates is one of the advantages of resin-modified GICs. However, low bond strengths of resin-modified GICs compared to those of resin composites remains a disadvantage $\mathrm{e}^{11)}$. Bonding systems for resin composites are commonly composed of three-step bonding protocols: conditioning, priming, and application of a bonding agent ${ }^{12,13)}$. Recently, two-step bonding systems have been developed using self-etching primers ${ }^{14-16)}$. Development of a further simplified bonding procedure would be beneficial to practitioners.

A new experimental primer, which functions as a single-step bonding system, was developed for a resin-modified GIC. The purpose of the present study was to evaluate the efficacy of this bonding system on adhesion of the experimental resin- 
modified GICs to enamel and dentin. In addition, bond strengths of a resin composite to tooth substrates using this system were also measured to assess the possibility of a single-step bonding system for composite restorations.

\section{MATERIALS AND METHODS}

\section{Materials used in this study}

The code and the batch number of the materials used in this study are listed in Table 1. The experimental primer, SR primer (Sankin Kogyo, Tokyo, Japan), was developed as a single-step bonding system, and included two bottles (Universal and Catalyst). One drop from each bottle was dispensed and mixed before use. SR primer contains 2-hydroxyethyl methacrylate (HEMA), tetra-methacryloxyethyl pyrophosphate, photoinitiators, ethanol and water. The primer indicated strong acidity, with a $\mathrm{pH}$ value of 0.6 . The two types of an experimental resin-modified GIC system, Xeno/SR-5111 (Sankin Kogyo, Tokyo, Japan), namely a paste type (PA) and a powder/liquid type $(\mathrm{PL})$, were used. Both materials contain almino-fluoro-silicate glass, tetra-methacryloxy-ethyl pyro-phosphate, HEMA, TEGDMA, Bis-GMA, and photoinitiators: A light-cured resin composite ( $\mathrm{RC}$ ), Clearfil AP-X (Kuraray, Osaka, Japan), was also used to evaluate the bond strengths of the resin composite to enamel and dentin using the experimental bonding system.

\section{Preparation of specimens}

The single plane shear test assembly designed by Watanabe et al. $(1988)^{17)}$ was used in this study (Figs. 1 and 2). Two plates were secured with rust-resistant screws to eliminate any movement during the bonding procedure and storage time. Bovine teeth were trimmed with a diamond saw and ground with \#600-grit silicon carbide paper ( $\mathrm{SiC}$ ) under a stream of water. The area for bonding was then demarcated

Table 1 Materials used in this study

\begin{tabular}{llll}
\hline Code & Manufacturer & Material & Batch No. \\
\hline $\begin{array}{llll}\text { Primer } \\
\text { SR }\end{array}$ & $\begin{array}{l}\text { Sankin Kogyo Co. } \\
\text { Tokyo, Japan }\end{array}$ & $\begin{array}{l}\text { Xeno/SR-5111 } \\
\text { (Experimental) } \\
\text { Universal, Catalyst }\end{array}$ & U:950514, C:960514 \\
& & &
\end{tabular}

Glass Ionomer Cement

$\begin{array}{llll}\text { PL } & \begin{array}{l}\text { Sankin Kogyo Co. } \\ \text { Tokyo, Japan }\end{array} & \begin{array}{l}\text { Xeno/SR-5111 } \\ (\text { Experimental) } \\ \text { Powder/Liquid Type } \\ \text { (P/L Ratio=4.4) }\end{array} & 960430, \text { L:95010 } \\ \text { PA } & & \text { Paste Type } & \end{array}$

Resin Composite

\begin{tabular}{llll} 
RC & $\begin{array}{l}\text { Kuraray Co. } \\
\text { Osaka, Japan }\end{array}$ & Clearfil AP-X & 0048 \\
\hline
\end{tabular}




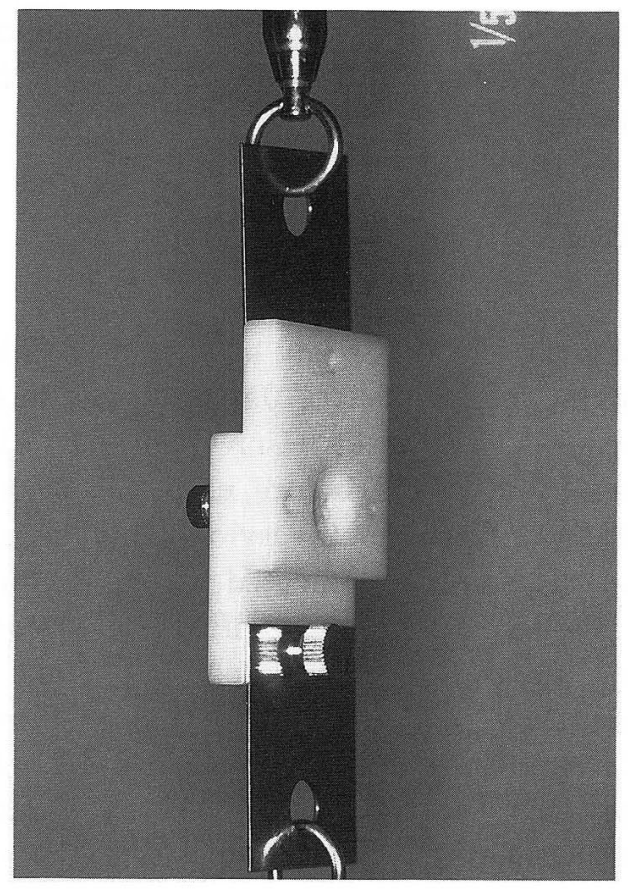

Fig. 1 Photograph of single plane shear test assembly

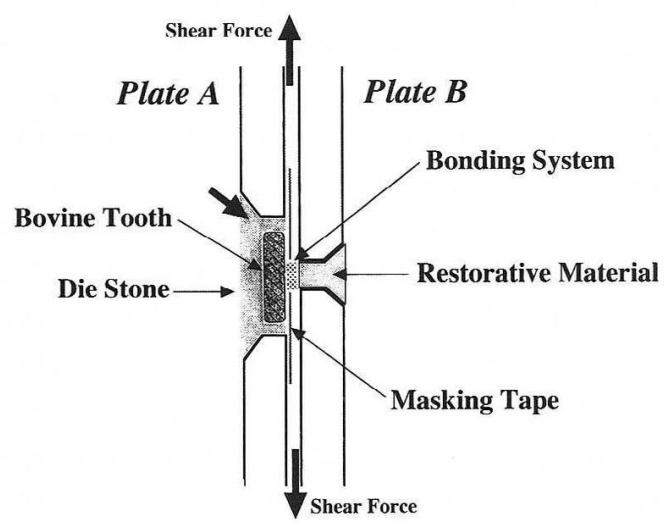

Fig. 2 Illustration of single plane shear test assembly

with vinyl adhesive tape with a hole $4 \mathrm{~mm}$ in diameter, and the specimens were mounted into the countersunk hole in plate A using a die stone (Fuji Rock, GC, Tokyo, Japan). After the die stone had completely set, the resin-modified GICs or the resin composite was placed in the countersunk hole in plate B using the bonding system described below. The bonding protocol was: (1) application of the experimental primer on the ground enamel or dentin surfaces for $30 \mathrm{~s}$, followed by gentle air drying, and (2) irradiation of visible light for 10s (single-coating group). Procedures (1) and (2) were repeated (double-coating group) in some groups to compare the bond strengths of the single-coating method with those of the double-coating method. Resin-modified GICs or the resin composite was applied to the treated surfaces and photoirradiated for 30s. After the specimens were prepared, they were stored in 37 ${ }^{\circ} \mathrm{C}$ water for $24 \mathrm{~h}$. The assemblies were attached to a universal testing machine ( $\mathrm{AG}^{-}$ 500B, Shimadzu, Kyoto, Japan) by alignments (Fig. 1). The screws holding plate A to plate B were removed just before loading, and shear bond strengths were measured at a crosshead speed of $2.0 \mathrm{~mm} / \mathrm{min}$. The number of specimens was ten for each group. The shear bond strengths for each group were compared statistically by one-way ANOVA and Fisher's PLSD test at the $5 \%$ level. 


\section{SEM observation}

To observe the enamel or dentin surfaces conditioned with SR primer, the occlusal enamel or dentin surfaces of human molars were ground with \#600-grit $\mathrm{SiC}$ under running water. The enamel or dentin surfaces were conditioned with SR primer for $30 \mathrm{~s}$ and further rinsed with acetone for $10 \mathrm{~s}$ to remove the applied primer. The specimens were dried at room temperature for 1 day, and desiccated in a high vacuum. They were then sputter-coated with gold, and the morphological changes of the enamel or dentin surfaces treated with SR primer were examined using a scanning electron microscope, SEM (JXA-840, JEOL, Tokyo, Japan).

In addition, to observe the resin-modified GIC-tooth interfaces, human molars were bonded as in the preparation of the shear bond specimens. They were soaked in formaldehyde for 1 day, then sectioned vertically at the interface using a diamond saw. The specimens were polished down to $1 \mu \mathrm{m}$ using a diamond paste. After desiccation, the specimens were etched with argon ion for $5 \mathrm{~min}$ according to Inokoshi's technique $(1993)^{18)}$. After gold-sputter coating, the resin-modified GIC/teeth interfaces were examined using an SEM.

\section{RESULTS}

The bond strengths to enamel and dentin are summarized in Table 2 and Table 3. Bond strengths to enamel were over $11 \mathrm{MPa}$ in all cases (Table 2). However, higher

Table 2 Shear bond strengths to enamel ( $\mathrm{MPa})$

\begin{tabular}{|c|c|c|}
\hline Code & Coating method & Shear bond strength \\
\hline \multirow[t]{2}{*}{ PL } & Single & $14.2(4.2)$ \\
\hline & Double & $15.7(5.0)$ \\
\hline \multirow[t]{2}{*}{ PA } & Single & $11.8(4.2)$ \\
\hline & Double & $16.8(4.1)]$ \\
\hline \multirow[t]{2}{*}{$\mathrm{RC}$} & Single & $11.2(3.5)$ \\
\hline & Double & $17.0(2.4)]$ \\
\hline
\end{tabular}

Mean (SD), $\mathrm{n}=10$

Vertical bars indicate significant differences at the $5 \%$ level.

Table 3 Shear bond strengths to dentin (MPa)

\begin{tabular}{llr}
\hline Code & Coating method & Shear bond strength \\
\hline PL & Single & $13.7(3.1)$ \\
& Double & $14.9(1.6)$ \\
\hline PA & Single & $9.0(2.5)$ \\
& Double & $12.8(3.7)$ \\
\hline RC & Single & $6.2(2.2)$ \\
& Double & $8.6(1.4)$
\end{tabular}

Mean (SD), $\mathrm{n}=10$

Vertical bars indicate significant differences at the $5 \%$ level. 

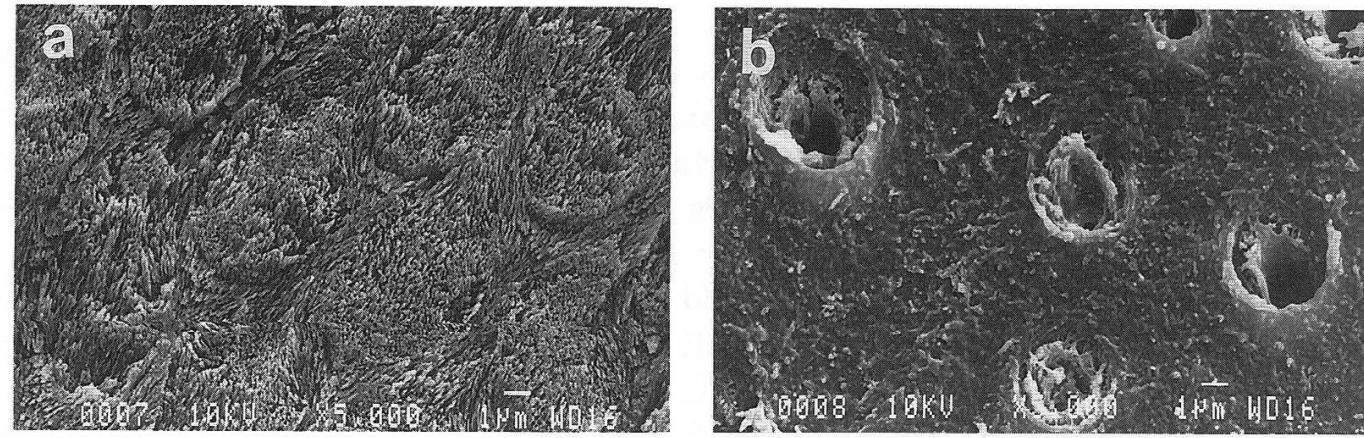

Fig. 3 SEM observations of the human enamel and dentin surfaces treated with SR primer $(\times 5000)$.

a. Enamel surface; The smear layer on the ground enamel was completely removed, and honey-comb structures were observed.

b. Dentin surface; The smear layer was removed and the dentinal tubules were observed, however, the smear plugs remained partially in the orifices.
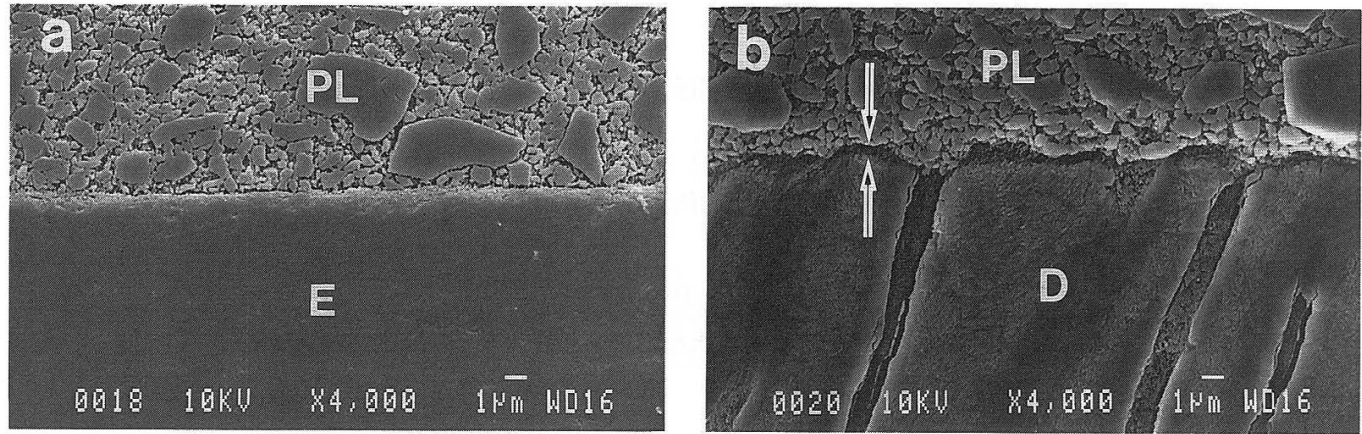

Fig. 4 SEM observations of the interfaces between PL and enamel or dentin $(\times 4000)$.

a. PL-enamel (E) interface

b. PL-dentin (D) interface; A hybrid layer (arrow) between PL and dentin were observed at the subsurface of the dentin. The depth of the hybrid layer irregularly ranged from 0.5 to $1 \mu \mathrm{m}$.

bond strength to enamel was obtained for PL, compared to PA and RC using the single-coating method. For PL, bond strengths to enamel showed no statistical differences between single-coating and double-coating, whereas bond strengths were significantly improved when a double-coat was applied prior to PA or $R C(p<0.05)$.

Using the single-coating method on dentin, bond strength was $14 \mathrm{MPa}$ for PL, while bond strengths were low for PA and RC. However, bond strengths of PA and RC to dentin significantly increased using the double-coating method $(p<0.05)$.

SEM observation of the enamel surface treated with SR primer (Fig. 3a) indicated that the smear layer on the ground enamel was completely removed, and honey-comb structures were observed; i.e., enamel peripheries were removed, leaving the prism cores intact. In the case of dentin, the smear layer was removed and the dentinal 
tubules were observed, however, the smear plugs remained partially in the orifices (Fig. 3b).

The cross-sectional views of the interfaces between PL and enamel or dentin are shown in Fig. 4. The photographs reveal good adhesion between PL and tooth substrates. A hybrid layer between PL and dentin was observed at the interface (Fig. 4b). The depth of the hybrid layer irregularly ranged from 0.5 to $1 \mu \mathrm{m}$.

\section{DISCUSSION}

Shear bond test assembly was standardized by the International Standards Organization (ISO) in 1993 ${ }^{19)}$. In a conventional assembly, it must be assumed that the shear blade can never be placed exactly at the bonding interface. However, when the blade is placed away from the interface, a bending moment will be created which could cause some deviation in the results. Formation of a small fillet of resin was also unavoidable in a conventional assembly, which may cause a change in the way that the stress distribution occurs during bond testing ${ }^{20)}$. The single plane shear test assembly designed by Watanabe et al. $^{17)}$ enables the shear force to load close to the interface between the tooth and bonding resin, and can eliminate the small fillet of bonding material (Fig. 2).

Bovine teeth were used in the shear bond test as a substitute for human teeth because of the large number of teeth required for this study, and because human teeth are scarce. In addition, the use of the bovine teeth makes it easy to obtain uniform surfaces for bonding, which are suitable for primary screening tests. However, it is very important to know the bonding performances of restorative materials to human teeth from the clinical stand point. Thus, human teeth were used in the SEM observations in this study.

PL provided good bonding to enamel and dentin even with single-coating of SR primer because of its good wettability to the cured primer compared to that of PA and RC. The resin matrix of PL seems to penetrate easily into the subsurface of the cured primer and be polymerized there, resulting in good formation of an interpenetrating polymer network (IPN). In contrast, PA or RC lacked affinity to the cured primer because of the low concentration of resin matrix in these materials, which resulted in limited penetration of monomers into the cured primer. In double-coating the SR primer in PA or RC, the secondly-applied primer can penetrate into the polymer network of the first layer of primer, and be polymerized, reinforcing the mechanical property of the primer. This reinforcement increases bond strengths to enamel and dentin. The bond strengths to dentin varied among these three materials even in the double-coating method, which might have been caused by the differences in elasticity among these materials ${ }^{21}$.

The SEM observations of the tooth surfaces treated with SR primer indicated that the primer functioned as a mild conditioner to enamel and dentin. The $\mathrm{pH}$ value of 0.6 was due to tetra-methacryloxy-ethyl pyro-phosphate included in the primer. The acidity of the primer was remarkably stronger than those of other primers in 
commercially available resin-modified GICs (Nikaido, unpublished results). In the previous study on a single-step bonding system, a methacryloyloxyethyl phenyl phosphoric acid (Phenyl-P) ${ }^{22)}$ was expected to be used for the multi-functional monomer for the system. Phenyl-P can remove the smear layer on dentin surfaces and penetrate into the subsurface of dentin ${ }^{14)}$. The SEM views of the interfaces between PL and enamel or dentin indicated that good adhesion was achieved using this system.

The hybrid zone ${ }^{23)}$ was observed at the interface between PL and dentin, which strongly suggested that the micromechanical interlocking between the primer and dentin is due to the bonding of the resin-modified GICs to dentin substrates. Such a zone has been previously reported by Shono $(1995)^{24)}$.

Bonding procedures of commonly used dentin adhesive systems require several steps to achieve good adhesion to dentin. The instructions of the bonding protocols vary according to each system, which may confuse practitioners, and cause technical errors during bonding procedures. Thus, further simplified bonding systems should be developed in order to reduce the technical sensitivity of the bonding systems. The present study suggested that a single-step bonding system could provide good adhesion of both resin-modified GICs and resin composite to enamel and dentin.

\section{CONCLUSION}

1. The experimental primer was a mild conditioner for enamel and dentin.

2. Double-coating of the primer improved the bond strengths of paste type resinmodified GICs and resin composite to enamel and dentin.

3. A hybrid layer between resin-modified GICs and dentin was observed.

4. It is suggested that a single-step bonding system could provide good adhesion to enamel and dentin.

\section{REFERENCES}

1) Tyas, M. J.: The effect of dentin conditioning with polyacrylic acid on the clinical performance of glass ionomer cement - 3 year results, Austr Dent $J 39$ : 220-227, 1994.

2) van Dijken, J.W.V.: Four-year evaluation of the effect of $10 \%$ polyacrylic acid or water rinsing pretreatment on retention of glass polyalkenoate cement, Eur $J$ Oral Sci 104:6466, 1996.

3) Swift, E. J.: Effect of mixing time on fluoride release from a glass ionomer cement, $A m$ $J$ Dent $1: 132-134,1988$.

4) Forss, H.: Release of fluoride and other elements from other light-cured glass ionomers in neutral and acidic conditions, $J$ Dent Res 72:1257-1262, 1993.

5) Antonucci, J. M., Mckinney, J. E., and Stansbury, J. W.: Resin-modified glass ionomer cement, US Pat. Appln. No. 160856, 1988.

6) Mitra, S. B.: Photocurable ionomer cement systems, Eur Pat. Appln. No. 032120 A2, 1989.

7) Eliades, G. and Palaghias, G.: In vitro characterization of visible light-cured glass ionomer liners, Dent Mater 9 : 198-203, 1993.

8) Blackwell, G. and Kase, R.: Technical characteristics of light curing glass-ionomers and compomers, Transactions of the Academy of Dental Materials 9:77-88, 1996.

9) Bell, R. B., Barkmeier, W.W.: Glass-ionomer restoratives and liners: Shear bond strength to dentin, $J$ Esthet Dent $6: 129-134,1994$. 
10) Triana, R., Prado, C., Garro, J., Garcia, Godoy, F.: Dentin bond strength of fluoridereleasing materials, Am J Dent 7 : 252-254, 1994.

11) Fritz, U. B., Finger, W. J. and Uno, S.: Resin-modified glass ionomer cements: Bonding to enamel and dentin, Dent Mater $12: 161-166,1996$.

12) Chen, R.S. and Bowen, R. L.: The use of $\mathrm{N}$-phenylglycine in a dental adhesive system, J Adhesive Sci Technol 3 : 49-54, 1989.

13) Burrow, M.F., Tagami, J., Negishi, T., Nikaido, T. and Hosoda, H.: Early tensile bond strengths of several enamel and dentin bonding systems, J Dent Res 73:522-528, 1994.

14) Watanabe, I., Nikaido, T. and Nakabayashi, N.: Adhesion to ground dentin: Investigation of bonding agent, Jpn $J$ Conserv Dent $33: 138-143,1990$. (in Japanese)

15) Nikaido, T., Yamada, T., Koh, Y., Burrow, M. F. and Takatsu, T.: Effect of air-powder polishing on adhesion of bonding systems to tooth substrates, Dent Mater $11: 258-264$, 1995.

16) Schumacher, G. E., Antonucci, J. M. and Bennett, P. S.: N-phenyliminodiacetic acid as an etchant/primer for dentin bonding, J Dent Res 73 : 277, Abstr. No. 1403, 1994.

17) Watanabe, L. G., Lacy, A. M. and Davis, D. R.: Shear bond strength: Single plane versus conventional lap shear, J Dent Res 67:383 Abstr. No. 2159, 1988.

18) Inokoshi, S., Hosoda, H., Harniratissai, C. and Shimada, Y.: Interfacial structure between dentin and seven dentin bonding systems revealed using argon ion beam etching, Oper Dent 18 : 8-16, 1993.

19) International Organization for Standardization: ISO TR 110405 dental materials - guidance on testing of adhesion to tooth structure, Geneva, Switzerland: WHO, 1993.

20) Kitasako, Y., Burrow, M. F., Nikaido, T., Harada, N., Inokoshi, S., Yamada, T. and Takatsu, T.: Shear and tensile bond testing for resin cement evaluation;Dent Mater 11 : 298-304, 1995.

21) Wakasa, K, Yamaki, M. and Matsui, A.: Adhesive systems - Dental resin interface and its fracture mechanism, Adhesive Dent $12: 79-80$, 1994. (in Japanese)

22) Yamauchi, J.: Study of dental adhesive resin containing phosphoric acid methacrylate monomer, J Jpn Dent Mater 5 : 144-154, 1986. (in Japanese)

23) Nakabayashi N.: Biocompatibility and promotion of adhesion to tooth substrates, CRC Crit Rev Biocompatibility $1: 25-52,1984$.

24) Shono, T.: Pulpal response to light-cured restorative glass polyalkenoate cements, and ultrastructure of cement-dentin interface, Jpn $J$ Conserv Dent 38(2):514-548, 1995. (in Japanese) 
PMMA レジンと比較し優れ，曲げ弾性率は PMMA と 同等であり，たわみ量はADAの規格値を満たしてい た。動的貯蔵弾性率に変化は認められず，コポリマー化
による分子の運動性への影響は認められなかった。各モ ノマーの重合取縮量は, MMA > PHMA > NBMA の 順に滅少した。

\section{メチルシクロヘキサンジオンを用いた象牙質接着用の新しい重合開始剂 今井庸二，石川美保 \\ 東京医科歯科大学医用器材研究所}

象牙質の接着における重合開始系の役割を調べる研究 の一環として，2-メチル-1.3-シクロヘキサンジオン (MCHD) と塩化第二銅からなる新しい重合開始系の効 果を，象牙質の前処理とレジン中の塩化第二銅の濃度の 影響について調べたものである。0.001-0.03\%の塩化第 二銅を含む $\mathrm{MMA}$ と $2 \%$ の $\mathrm{MCHD}$ を含む PMMA と から成るレジンを用いて，硬化時間と牛歯象牙質に対す る引張り接着強さを測定した。象牙質表面は，0-3\%
の塩化第二鉄あるいは塩化第二銅を含む10\%リン酸ある いはクエン酸の前処理剤で処理した。適切な条件下では 約 $10 \mathrm{MPa}$ の接着強さが得られ, この值は現在最も效果 的な接着性レジンであるトリブチルボランを開始剤とす る MMA レジンに匹敵するものであった。このように， $\mathrm{MCHD} /$ 塩化第二銅の重合開始系を用いたレジンは象牙 質の接着に非常に効果的であることがわかった。

\section{1 ステップボンディングシステムのエナメル質,}

象牙質に対するせん断接着強さ

二階堂徹, 中島正俊, 東 高士, 金村信晴, パトリシア N.R.ペレイラ, 田上順次

東京医科歯科大学歯学部歯科保存学第一講座

1 ステップで接着操作を完了できる試作プライマーが開 発された. このプライマーを用いて, 光硬化型グラスアイ オノマーセメントならびにコンポジットレジンの歯質接着性 について検討した。 せん断接着試験の結果，エナメル質に 対する良好な接着性が確認されたが（>11MPa），象牙 質に対する接着性は低かった。 しかし，試作プライマーの 塗布, 光照射の操作を 2 回繰り返すことにより, 象牙質に
対する接着強さの向上が認められた（>8MPa）. SEM 観察の結果，試作プライマーは，エナメル質，象牙質に対 して，マイルドな脱灰効果を有し，さらに光硬化型グラス アイオノマーセメントと象牙質との接着界面には，樹脂含 浸層の形成が確認された．以上の結果から，1 ステップの ボンディングシステムにおいても良好な歯質接着性が得ら れる可能性が強く示晙された。

\section{石こう系クリストバライト埋没材鋳型における異方性䐍張} 渋谷昌史，大澤雅博，松元 仁，久恒邦博1，安田克廣 ${ }^{1}$ 長崎大学歯学部歯科保存学第一講座

${ }^{1}$ 長崎大学歯学部歯科理工学講座 